\title{
Gender Equality in Turkish Higher Education
}

\author{
Fatma Çobanoğlu ${ }^{1}$ \\ ${ }^{1}$ Faculty of Education, Pamukkale University, Denizli, Turkey \\ Correspondence: Fatma Çobanoğlu, Faculty of Education, Pamukkale University, Denizli, Turkey. Tel: \\ 90-258-296-1074. E-mail: fcobanoglu@ pau.edu.tr
}

Received: September 17, 2018

Accepted: September 27, 2018

Online Published: September 28, 2018

doi:10.5430/ijhe.v7n5p97

URL: https://doi.org/10.5430/ijhe.v7n5p97

\begin{abstract}
The moulds of masculinity and femininity determined by society are not only determinants of the way in which individuals behave in society, but also determinants of the production and distribution of the resources. The steady development of societies can be achieved when men and women have the equal power with equal opportunities and resources to shape their own lives and to contribute to their families, societies and countries. The internationally recognized indicators of aforesaid gender mainstreaming are the areas of Economic Participation and Opportunity, Educational Attainment, Health and Survival, and Political Empowerment. In Turkey, even though the legal basis of equality of women and men in these areas have been strengthened through legislative regulations enforced, the need to overcome the obstacles women face when participating to social life as complete and equal individuals and taking all precautions for this is still ongoing. In this study, gender equality in the Turkish higher education system was examined. For this purpose, the schooling rates in higher education, employment rates and participation rates in decision making mechanisms in management of women were examined in the light of gender equality indicators. In this study, which was conducted by document reviewing among qualitative research methods, official websites and documents of international organizations and Turkish official institutions were examined in order to access reliable documents related to Turkish Higher Education and gender equality variables. The survey concluded that while the schooling rates in the Turkish higher education and employment rates of women are high, the proportion of female academicians decreased as the academic degrees increased and that the horizontal disintegration patterns between the scientific areas are more visible on the basis of sub-branches. Furthermore, it has been found out that women are not adequately represented in decision-making mechanisms, even though they provide the necessary conditions.
\end{abstract}

Keywords: women, gender equality, higher education, women academician

\section{Introduction}

The society in which the individual is raised shapes him/her in behavioural patterns that are related to femininity and masculinity. These roles that are defined as gender and attributed to woman and man direct the life of the individual; canalize woman and man to different knowledge, life experiences, activities, and needs.

These woman and man patterns that are identified by the society do not only differentiate the man and woman but also differentiate their access to social resources and experiences to a great extent. Moreover, gender is a significant variety resource in producing and distributing the resources (Yumuş, 2011:3). In this context, West and Zimmerman (1987) define the gender as "a powerful ideological device, which produces, reproduces, and legitimates the choices and limits that are predicated on sex category". Gender phenomenon is an inequality problem that is experienced in many countries and societies around the world even though how deep the problem is, is not stable (Bingöl, 2014). As it is seen, it draws our attention that the gender phenomena lead to a differentiation between woman and man in the definitions. This has recently made it necessary for many countries to develop new policies on gender equality because no country can develop constantly if they do not transform the distribution of opportunities, resources and choices for man and woman to make it possible for them to have equal force to form their lives and make contribution to their family, society and countries (World Bank Group Gender Strategy Paper 2016-2023, p.7).

Gender equality refers to "the equal rights, responsibilities and opportunities of women and men and girls and boys" it also hints that "the interests, needs and priorities of both women and men are taken into consideration, recognizing the diversity of different groups of women and men" (UNESCO Priority Gender Equality Action Plan - 2014-2021). Historically, most inequalities based on gender have put women at a disadvantage and a strong international policy framework regarding that women have rights. In the past decades, multiple instruments have been developed by 
countries around the world to help them achieve gender equality and women's empowerment.

The base of the gender equality policies in Turkey are the reforms of the Republican period. In the following years of the establishment of the Republic, a modern governmental structure was established and also a significant societal change was implemented by reforms made with the belief that the women and men should have completely equal rights (women gained equal education rights as men in 1924, women gained adapting to social life and fundamental rights in 1926, women gained right to vote and stand for an election in local governments and women gained the right to elect the representatives and to be elected as representatives in 1934). What lies under these reforms is that women join in the public space and contribute to the development process with men (The Gender Equality National Action Plan 2008-2013). Atatürk reflects a contemporary view with his main thoughts in 1923 by saying that "it is necessary to believe that everything you see in this world is the piece of work of the woman" and also said that "the real reason behind the failure of the society stems from ignorance towards women and while an organ of the society is active, the other one is not, then that society becomes paralyzed" (Aydın 2015).

Via the international conventions which were accepted in today's Turkey, (The Convention on the Elimination of all Forms of Discrimination against Women (CEDAW), The Convention of Council of Europe on the Prevention and Combat against Violence Against Women and Domestic Violence (İstanbul Convention), United Nations 2030 Sustainable Development Goals) and via national policy documents (National Action Plan for Gender Equality; Women's Empowerment Strategy Document and Action Plan, National Action Plan to Combat Violence Against Women; Strategy Document and Action Plan for Combating Premature and Forced Marriages with national policy documents), it was tried to ensure that women have equal opportunities in terms of participation in education, health, work life, politics and decision-making mechanism which are the fundamental areas of life, but when the present position of Turkish woman in the society is analysed, gender inequality is seen obviously as demonstrated in (Table 1).

Table 1. The rank and scores of Turkey in Global Gender Gap Index 2017

\begin{tabular}{llllllllllll}
\hline & \multicolumn{3}{l}{ Global Index } & & \multicolumn{2}{l}{$\begin{array}{l}\text { Economic } \\
\text { Participation } \\
\text { and Opportunity }\end{array}$} & $\begin{array}{l}\text { Educational } \\
\text { Attainment }\end{array}$ & $\begin{array}{l}\text { Health } \\
\text { Survival }\end{array}$ & and & $\begin{array}{l}\text { Political } \\
\text { Empowerment }\end{array}$ \\
& Rank & Score & Rank & Score & Rank & Score & Rank & Score & Rank & Score \\
\hline Turkey & $\mathbf{1 3 1}$ & 0.625 & $\mathbf{1 2 8}$ & 0.471 & $\mathbf{1 0 1}$ & 0.965 & $\mathbf{5 9}$ & 0.977 & $\mathbf{1 1 8}$ & 0.088 \\
\hline
\end{tabular}

Source: Global Gender Gap Index 2017.

Note: 144 countries featured in the 2017 index.

Score: $0.00=$ imparity $1.00=$ parity

The features that are seen equivalent to "womanhood" in Turkish society are firstly the features about femininity rather than the features of an equal, independent, unique individual. Firstly, spouse, mother or a member of the family equivalents are attributed to the woman who is seen to represent the femininity. There are qualitative and quantitative imbalances between men and women in their existence in world of education and politics. Less women have right to be educated and in Turkey, being woman is seen to be a disadvantage to be interested in politics (Bingöl, 2014). With the legislative reforms, the legal basis of equality between men and women is strengthened, and also the need to overcome the obstacles that women face in their participation in the social life as full and equal individuals and to take all the precautions against this problem still continues (KSGM, 2018). There are still significant problems related to gender equality especially in education area. Compared to the EU countries, the schooling status of girls in the Turkish education system and therefore the gender equality index is lower than boys in terms of the current situation at all levels of education, and the education span which is expected yearly is increasing (Maya, 2013).

Gender mainstreaming has a critical importance within education and via education with regard to gender equality. Investing in education area is a significant driving force in economic and social growth because it enhances the incomes that are open to the general public and private incomes (GPE Policy Brief 2016). Considering Turkey, particularly in the Constitution (Article 42, 1982 Constitution) also in 1739 National Education Basic Law, basic principles that supply equal opportunity and possibility to women and men were accepted and it was also accepted that education institutions are open to everyone. With the amendment made in 2012 on Primary Education and Training Law No. 222, 12-year intermittent education has become compulsory for every citizen. The aim "to ensure all individuals to access education and training under fair conditions" and "to increase the rates of attendance and 
completion mainly for disadvantageous groups and on every stage of education and training" which was stated in 2015-2019 Strategical Plan by Ministry of Education have a vital importance for the education system to encompass every child in Turkey. In 2017-2018 academic year, while the sex ratio at primary level is $99.84 \%$, at lower secondary school level is $101.76 \%$, this ratio is $93.25 \%$ for secondary education throughout Turkey (Ministry of National Education statistics) and significant differences are observed in some regions and provinces. The gender ratio for higher education is $93.28 \%$ and the introduction to higher education forms relatively less problem for the women who completed the primary and secondary education processes.

\subsection{Gender Equality in Turkish Higher Education}

Higher education (HE) contributes to individual welfare by including advanced work force to the society and enhancing the social welfare as well as improving the level of income the individuals acquire. The benefits of HE to the individuals and the society increases the demand for HE day-by-day (Aydemir and Uysal, 2016). At this point, it is vital for gender equality that both women and men benefit from HE equally considering the increasing demand.

In Turkey, women had the right to HE in Constitutional Monarchy period on February 7, 1914, when Darülfünun (University) started to accept girls (Özkul and Baysal, 2017)). Along with the declaration of Republic, the first university in Turkey was established in 1933 nearly 10 years after the regime was constituted. "Darülfünun" which means "Ottoman University" was reshaped under the name of "İstanbul University". Since then, many universities have been established in Turkey. Today, there are 206 higher education institutions (129 state universities, and 77 private universities).

The universities which are the visible constitutions of modernization and westernization became one of constitutions which symbolize the ideals in relation to Republican Turkish women and they were shaped thanks to the participation of women from the very beginning. Turkey had a remarkable position for a way long period with women ratio in the fields of academicians, professorial staff, natural sciences, engineering and the possible reasons of this are might be because women are directed to the education via republic reforms, academic careers for women are historically and socially "safe" and "appropriate" or graduate men traditionally prefer financially better jobs (Öztan and Doğan 2015).

Despite international gender equality declarations, some studies (Tunç, 2017; Yılmaz, 2017; Seskir 2017; Savigny, 2014; Machado-Taylor and Özkanl1, 2013; Özkaplan, 2013; Lewis and Humbert, 2010; Kjedal, Rindfleish and Sheridan, 2005) show that academic areas are characterized by gender based practices. Even though in relation to gender equality in Turkey various researches have been carried out on schooling rate in accessing the HE (Günay and Günay, 2016; Seskir, 2017), women in academic life (Adak, 2018; Altınoluk, 2018; Yenilmez 2016; Karakuş. 2016) and representation of women in the management of higher education (Tahtalıoğlu, 2016; Suğur and Cangöz, 2016; Çalışkan Maya, 2012), there is still not a recent research which examines and evaluates all these dimension across Turkey. For this reason, the gender equality in HE should be researched in more detail. The purpose of this study is to examine schooling, employment, advancement rates in academic area and participation rates in decision-making mechanisms in HE of women in Turkish HE system by benefiting from the data of education, participation in employment and decision-making of gender equality indicators.

\section{Method}

Document analysis, a type of qualitative research method, was used in the research. Qualitative Document Analysis is a research method that is used to analyse written documents meticulously and systematically for a specific purpose.

In the document analysis, it is very important to reach the related documents, to check the authenticity of the documents reached, to analyse and use the data (Yıldırım and Şimşek, 2013, p. 223). For this reason, it was decided to examine official websites and documents of international organizations and Turkish official institutions in this research in order to reach reliable documents on Turkish HE and gender equality variables. In this context, in the research, statistics of Council of Higher Education (CoHE), reports of the Prime Minister Directorate General on the Status of Women, statistics of Turkish Statistical Institute (TurkStat), education statistics of Ministry of National Education were used for data related to Turkey. In order to determine the position of gender equality in Turkish HE on the international platform, statistics of the European Institute for Gender Equality (EIGE), OECD, World Bank, UNESCO, World Economic Forum and the survey of the body of literature related to the topic were used. In this context, the reliability of the data is guaranteed by accessing the primary sources directly. Furthermore, the relevant body of literature was scanned and the topics on "gender equality in higher education", "schooling rates of women in higher education", "women in academia" and "women administrators in higher education" were focused. 
The documents obtained as a result of scanning the related body of literature were analysed by descriptive analysis method. Similar data are coded under certain concepts, and these concepts are brought together under a theme. In other words, data collected to determine the highest level of gender equality in higher education were organized and presented in graphical form with three main themes; women as students, women as academicians and women as administrators, and sub-themes under each main theme. In addition, it has been interpreted taking into account the relevant body of literature.

In order to ensure the reliability and validity of the data, official websites and documents of international organizations and Turkish official institutions which are publicily and currently available were examined. Furthermore, these data sources were defined elaborately for easy access.

\section{Results}

While gender equality in HE is studied, the proportion of women as students in HE, the proportion of women who found the opportunity to work in the academy, and finally the proportion of women in the decision-making mechanisms of HE are examined respectively.

\subsection{Woman as a Student in HE}

HE covers all the secondary education-based education institutions, providing at least 2 years of higher education. Each university consists of faculties at the level of bachelor degree and vocational colleges with four-year bachelor degree and two-year associate degree. The postgraduate education consists of graduate and doctorate programs coordinated by the institutes for post graduate studies. An annual national examination is conducted by Assessment Selection and Placement Centre (OSYM), which is also the centre for transition to higher education.

Turkey's population is approximately 81 million and $50.2 \%$ of the population is men, while $49.8 \%$ of the population is women. In addition, it has a very high youth population (the ratio between the ages of 15-64 is 67.9\%, TurkStat, 2017). The need of HE for such a young and dynamic society is also increasing. The school enrolment rates of the Turkish population at the level of tertiary education over the years are shown in Graph 1.

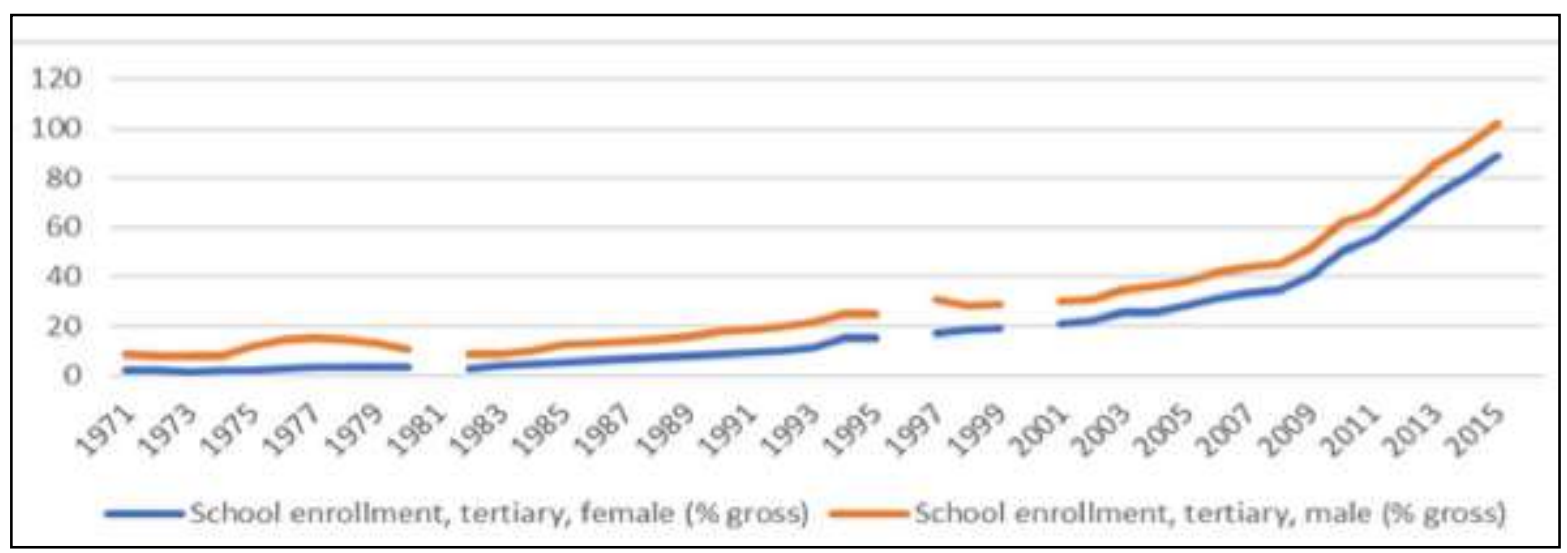

Graph 1. Enrolment rates in tertiary education (1971-2015)

Source: Gathered from World Bank data.

Turkey, has achieved an increase in the school enrolment rates in tertiary education for both women and men every year. Gender parity index (GPI) values obtained are given in Graph 2 when this increase is observed in terms of genders. 


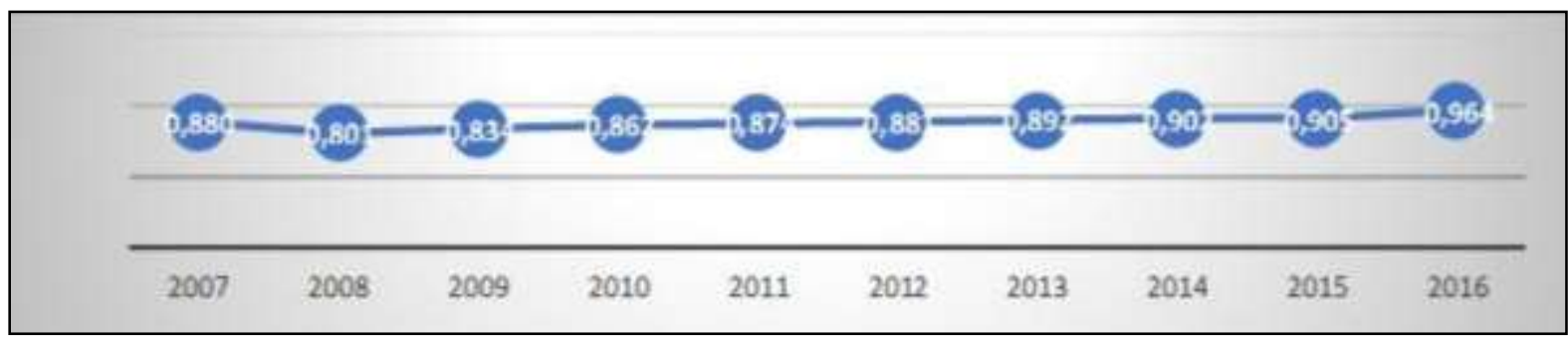

Graph 2. GPI values in tertiary education (2007-2016)

Source: TurkStat, Women in Statistics, 2017

Note: GPI value expresses the relative size of the female students' gross schooling rate to the male students' gross schooling rate. If it is equal to 1 , this means there is an equality between male and female students, if it is smaller than 1 , it shows inequality on behalf of male. If it is greater than 1 , then it shows inequality on behalf of female.

From a more detailed perspective, gender based explicit schooling ratios in tertiary education for the last five years are given comparatively in Graph 3.

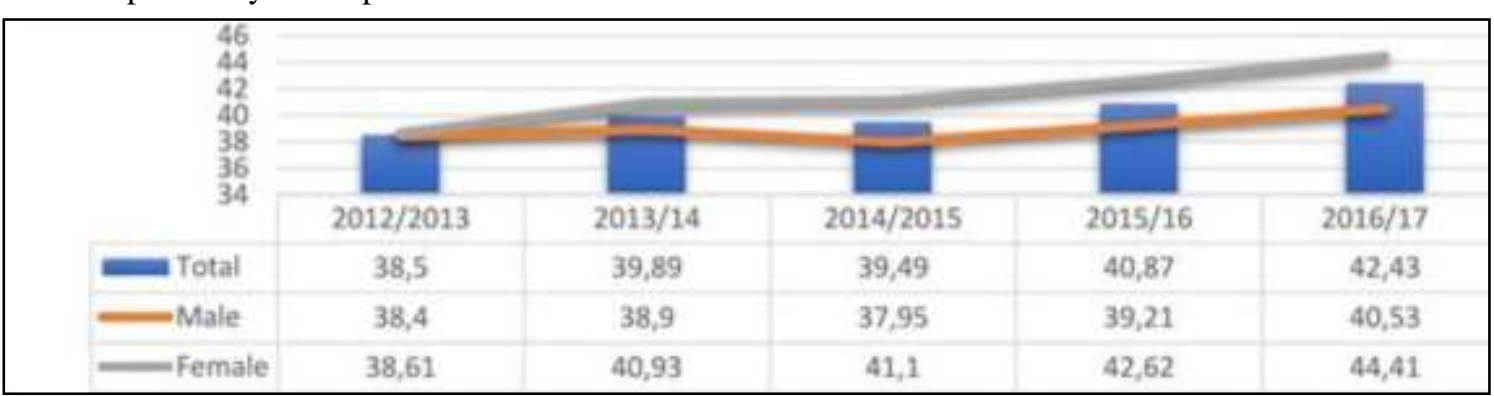

Graph 3. Gender based explicit schooling ratios in tertiary education (2012-2017)

Source: National Education Statistics 2016/17

When the schooling rates in the Turkish HE system are examined; it is observed that the rates of schooling of women have increased steadily over the past five years and have also increased above the total schooling rates. The number of students based on gender and grades (associate degree, bachelor's degree, master's degree and doctorate) in HE are also given below.

\subsubsection{Associate Degree Programs}

It is a HE program based on secondary education qualifications, aimed at training qualified labour force, covering at least a two-year program or constituting the first level of bachelor degree (The law no. 2547). The number of students enrolled in these programs is given in Graph 4 and it is observed that the rates of schooling of women and men have increased steadily over the past five years.

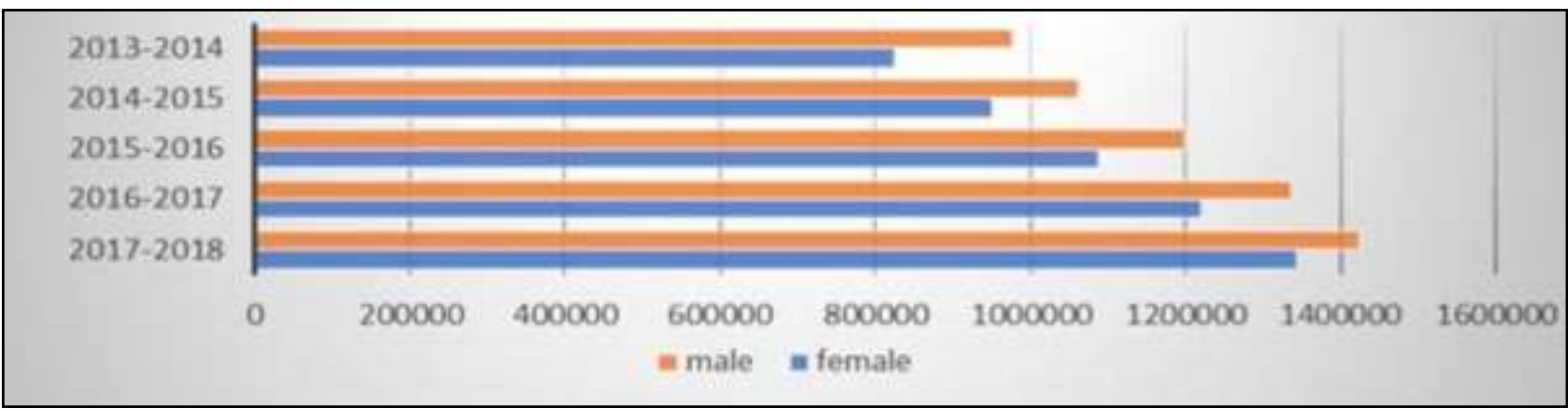

Graph 4. Number of students at associate degree level (2013-2018)

Source: CoHE, 2018

\subsubsection{Bachelor Degree Programs}

Bachelor degree programs may last generally for four years, depending on secondary education, but may last even longer in some areas of specialization, such as medicine. The number of students enrolled in these programs is given 
in Graph 5 based on their gender.

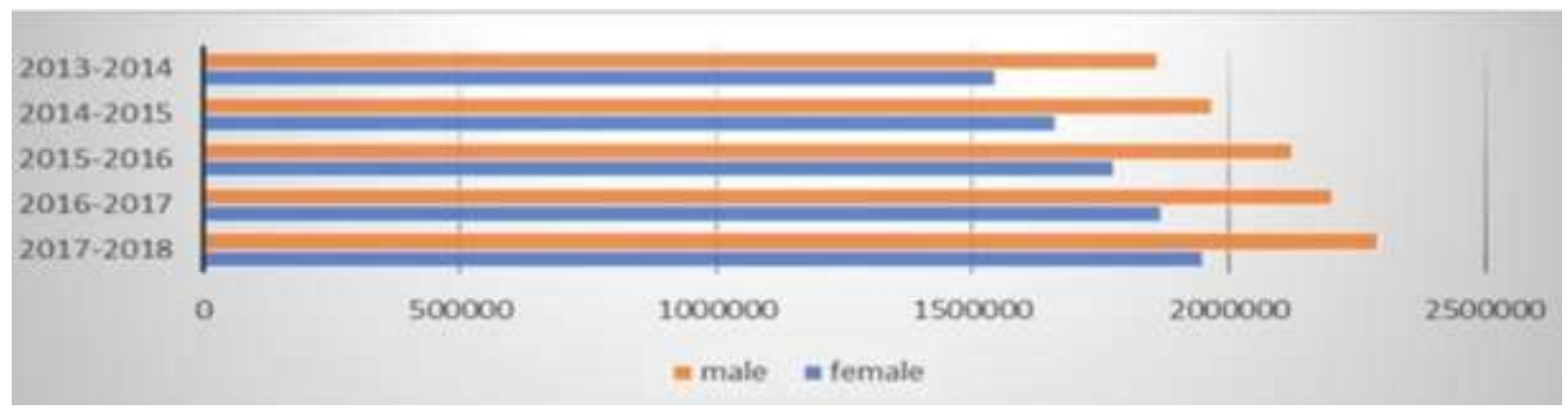

Graph 5. Number of students at bachelor degree level (2013-2018)

Source: CoHE, 2018

When the field preferences of the students who settled in the undergraduate programs in 2017-2018 academic year are examined; it is found out that male students prefer rather engineering, production, business, management, law, agriculture and livestock and information and communication fields while female students prefer rather health and education fields (Graph 6). Looking at the details, the areas where women are numerically overrepresented are biology and mathematics and statistics in the field of Natural Sciences, Mathematics And Statistics; all sub-branches in the field of education but especially pre-school teachers; security services in the field of services; food, chemistry and textile engineering, architecture and urban planning in the field of Engineering, Manufacturing And Construction; social work and counselling, dentistry, pharmacy, nursing and midwifery and medicine in the field of Health And Welfare; science of religion, philosophy and ethics, language acquisition and linguistics, crafts, fine arts, fashion and industrial design in the field of Arts and Humanities; library, information and archival studies in the field of Social Sciences, Journalism and Information; psychology, sociology and cultural studies; and law and finance with by a narrow margin in the field of Business, Administration and Law are the sub branches.

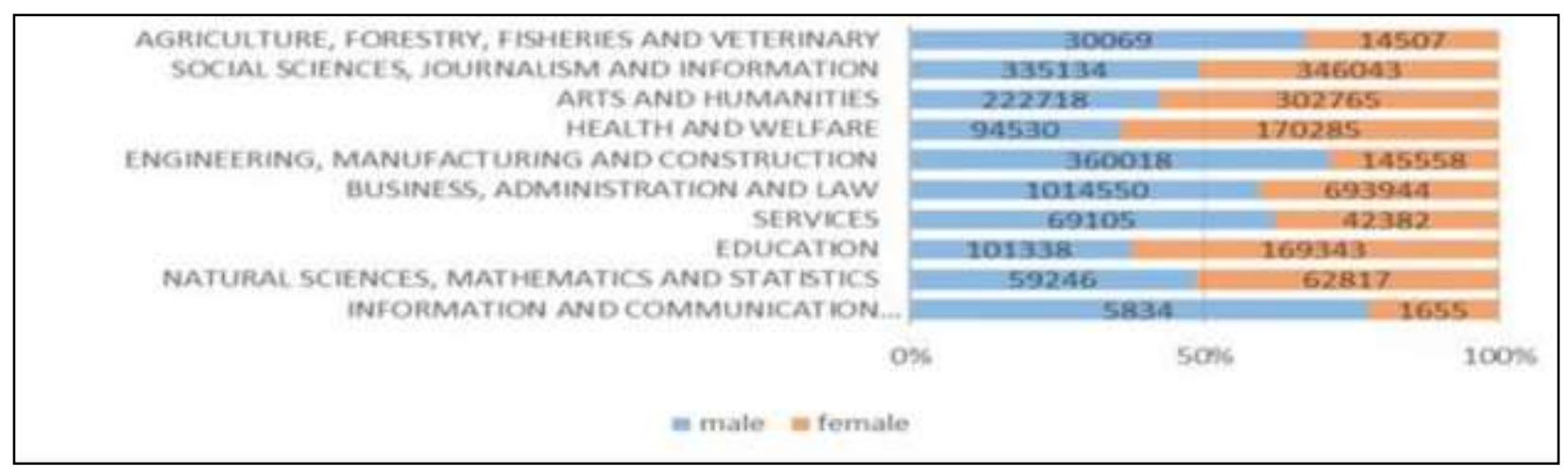

Graph 6. Number of undergraduate students by classification of fields of education and training (2017/2018) Source: CoHE, 2018

\subsubsection{Master Programs}

It is a HE program based on bachelor degree, aiming to reveal the results of education-training and research and lasts two years. When the students who attend the master programs are examined by their gender, it is seen that there are more male students. (Graph 7) 


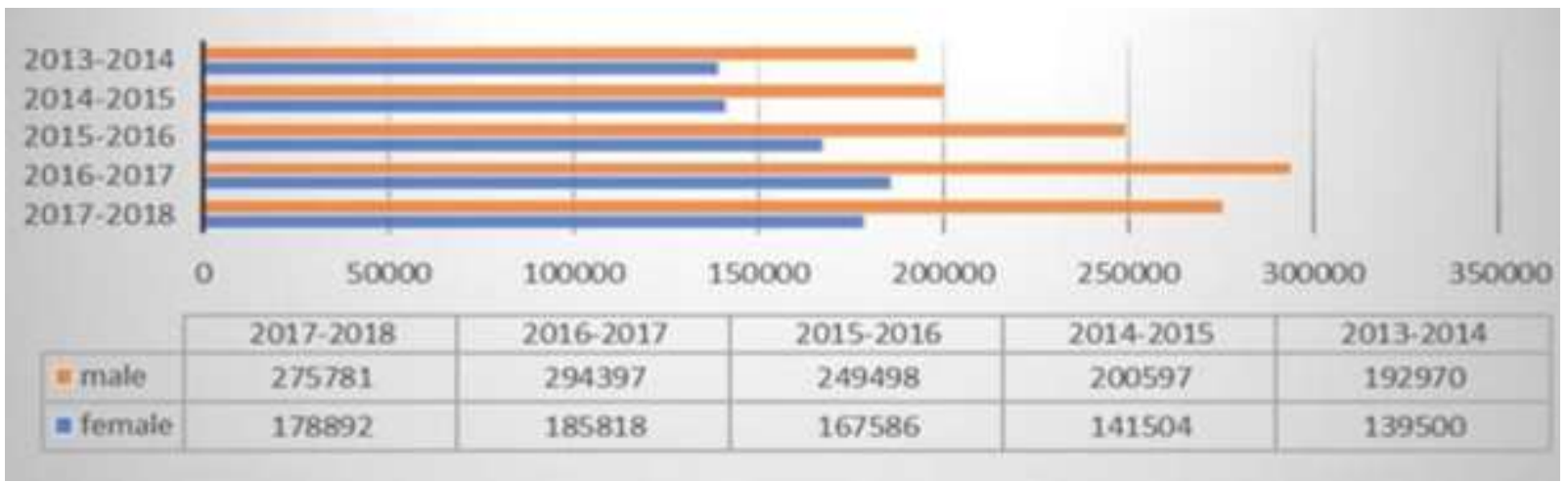

Graph 7. Number of students at master's level (2013-2018)

Source: CoHE, 2018

\subsubsection{Doctorate Programs}

It is a four-year higher education program based on teaching a bachelor or master, aiming to demonstrate the results of education-training and research. Between 2002 and 2012, the number of women at PhD level grew generally at a faster rate than the number of men. This ratio is 9.7 for women, while for men it is 3.9 (She Figures, 2015). When the status of those continuing to a doctorate program over the years is examined, it can be said that although the number of men doing doctorate is high, the demand of women and men to do doctorate has increased in similar rates. The number of students who attend doctorate programs are given in Graph 7 by their gender.

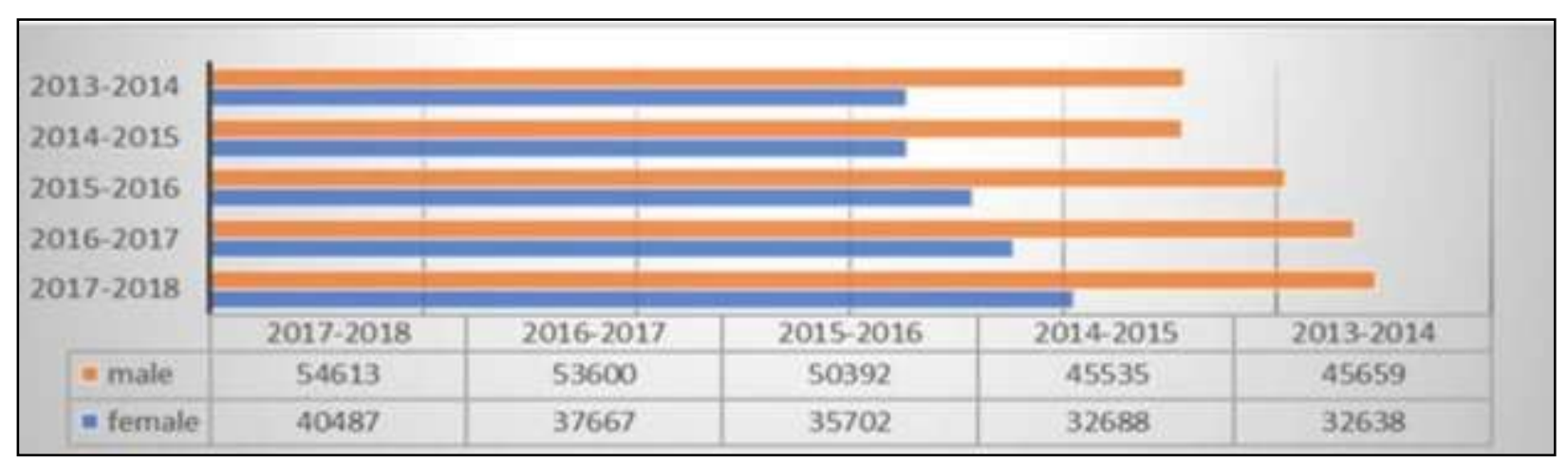

Graph 8. Number of students at doctorate level (2013-2018)

Source: CoHE, 2018

Regarding field preferences, which is another phenomenon of gender equality in HE, it can be said that women and men who want to do master and doctorate degree, prefer postgraduate programs in similar proportions to their bachelor degree programs (Graph 9). It is seen that women prefer postgraduate education in the fields of education, health and arts, while men prefer especially business, administration and law, engineering and manufacturing fields. 


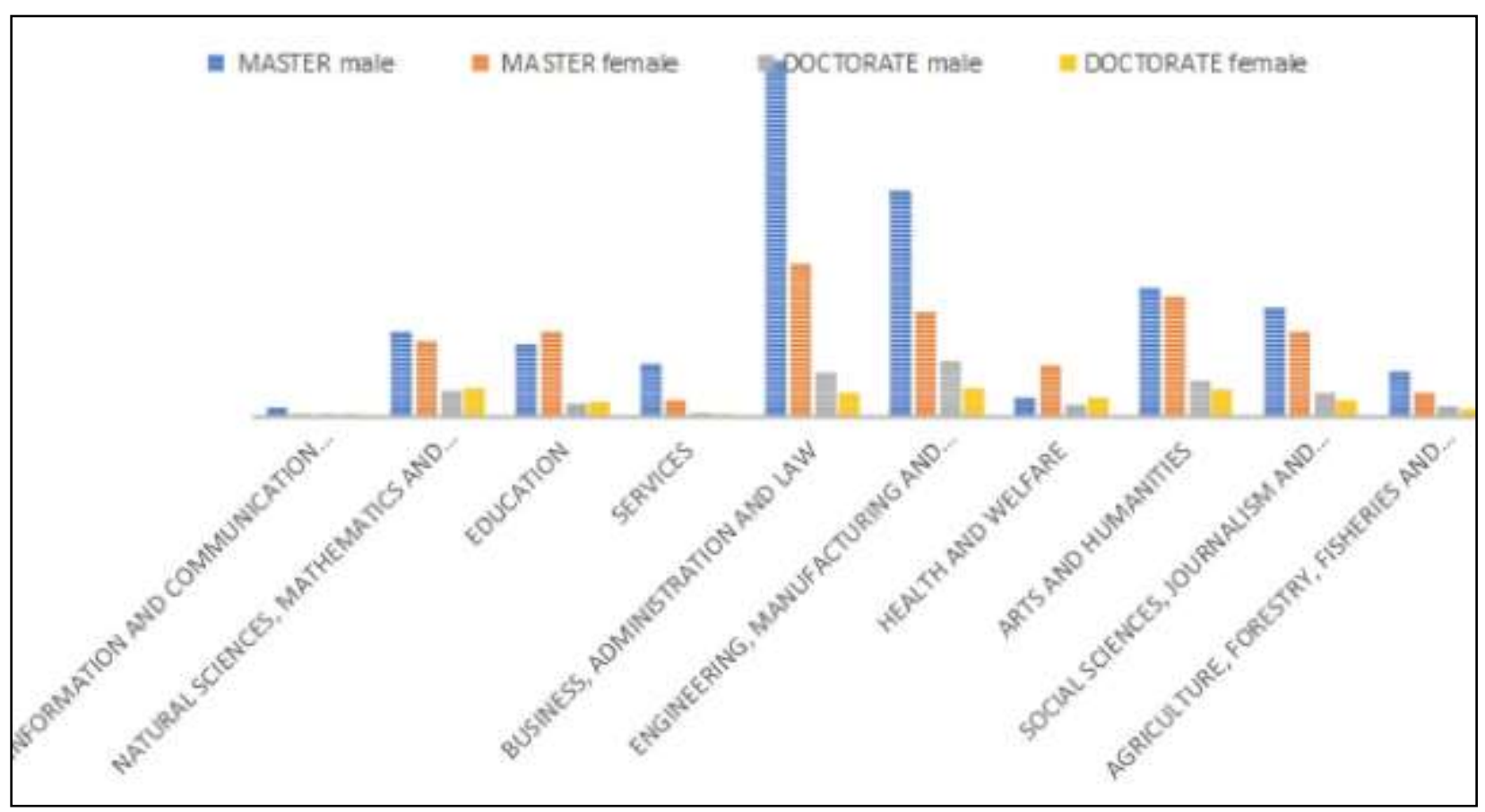

Graph 9. Number of graduate students by classification of fields of education and training (2017/2018)

Source: CoHE, 2018

\subsection{Women as Academicians in HE}

Although women took part in academic fields for the first time in 1932, large scale employment of women in these fields occurred in 1940s (Köker, 1988). It is observed that Turkish HE has gone a long way from that day to this, and that female teachers are employed in HE with a ratio of (43\%), which is higher than the world average (Graph 10). According to researchers, compound annual growth rate in the HE sector by gender is 8.1 for women and 6.3 for men between the years 2005-2012 (She figures 2015).

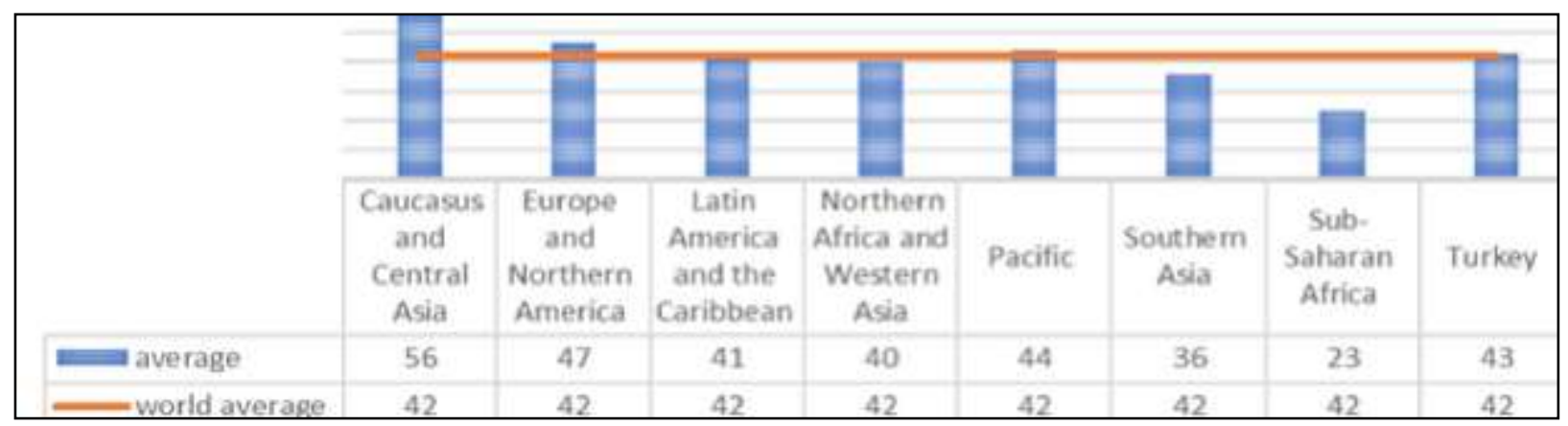

Graph 10. Percentage of female teachers (\%) in tertiary education

Source: Gender Equality in Education, Global Education Monitoring Report 2017/8

The distributions of academicians working in HE institutions by gender are given in Graph 11 in comparison with their academic titles. 


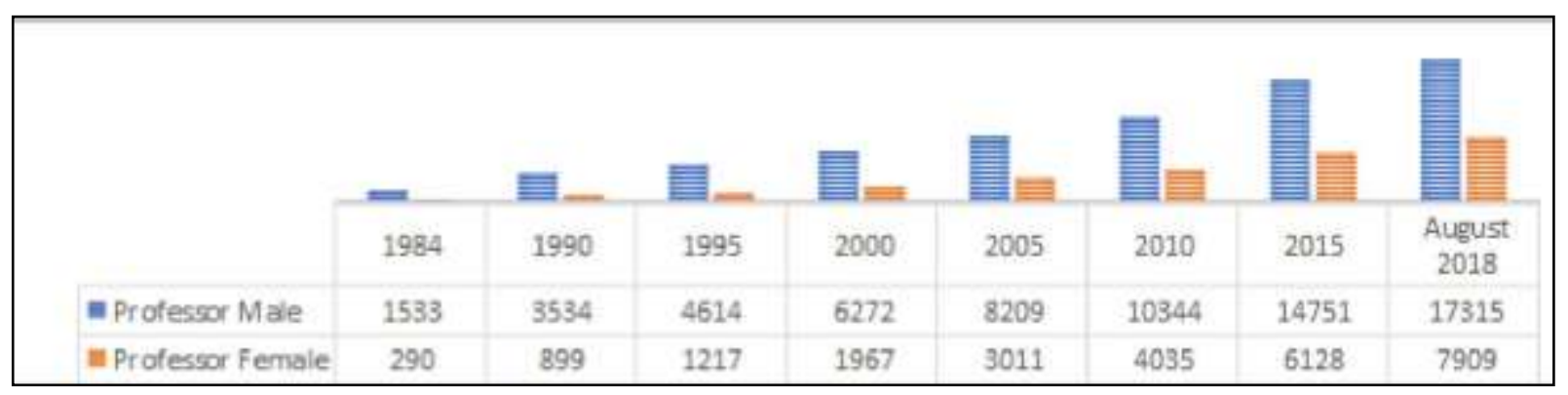

Graph 11. Distribution of the academicians in the professor position by gender

Source: CoHE, 2018

Graph 11 shows that since the starting year, despite the increase in both male and female professors, the rate of increase in women is higher than that of men. Compared to the number of male professors who were initially over five times more, today the number of female professors constitutes $31 \%$ of the total number of professors.

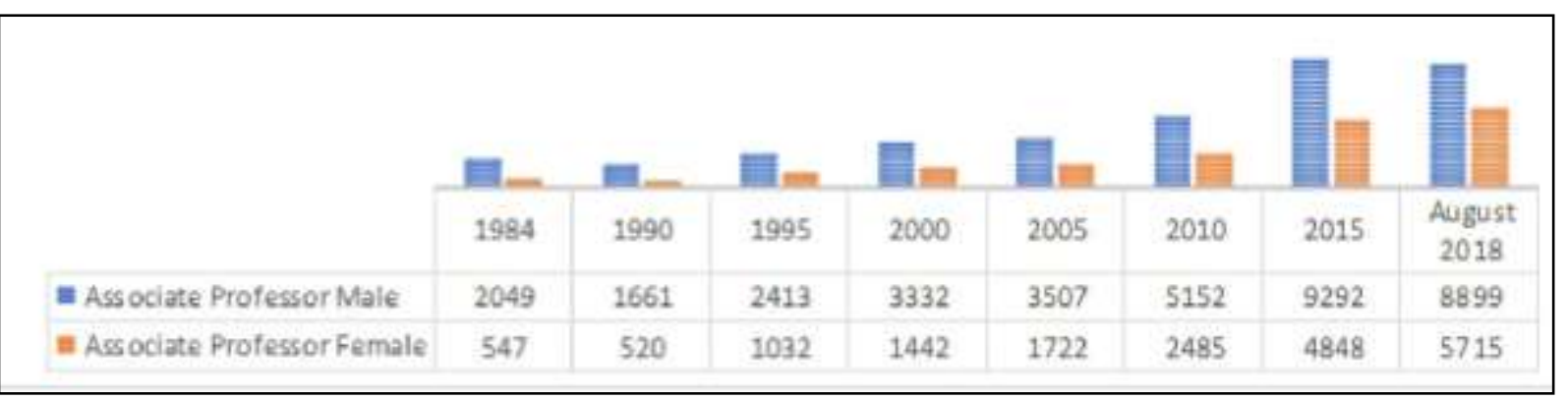

Graph 12. Distribution of the academicians in the associate professor position by gender

Source: CoHE, 2018

As in the case of the professors cited above, there has been more increase in the number of female associate professors over the years compared to that of male colleagues. At the beginning, the proportion of women representing $21 \%$ of the total associates has now risen to $39 \%$.

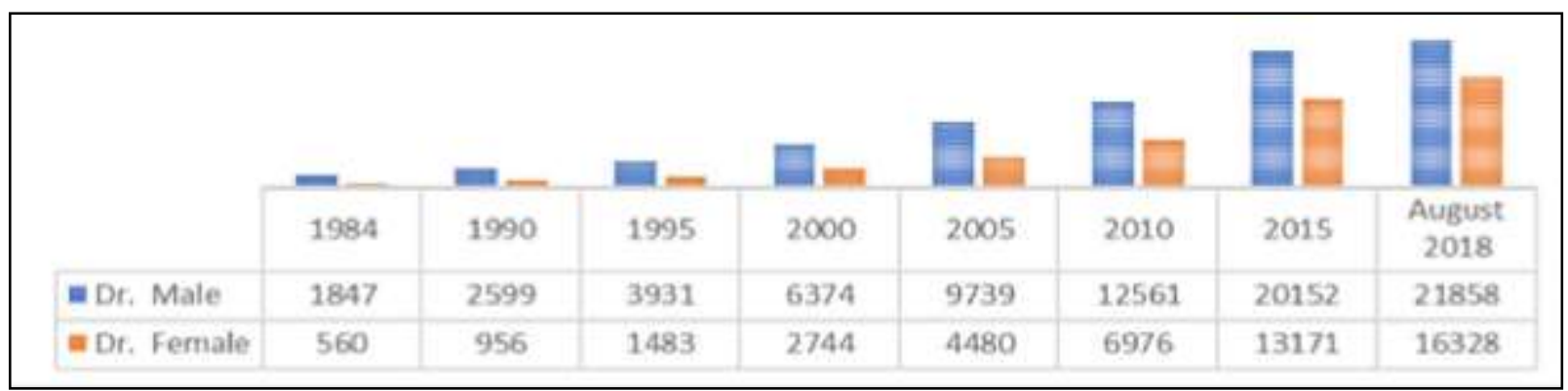

Graph 13. Distribution of the academicians in the Dr. position by gender

Source: CoHE, 2018

As is seen in the period given in Graph 13, despite the disadvantages of the first years, there has been an increase in the number of female academicians in the Dr. position, which is an intermediate in transition to associate professorship after graduating from doctorate, and the percentage of women with this title has reached approximately $43 \%$ in total. 


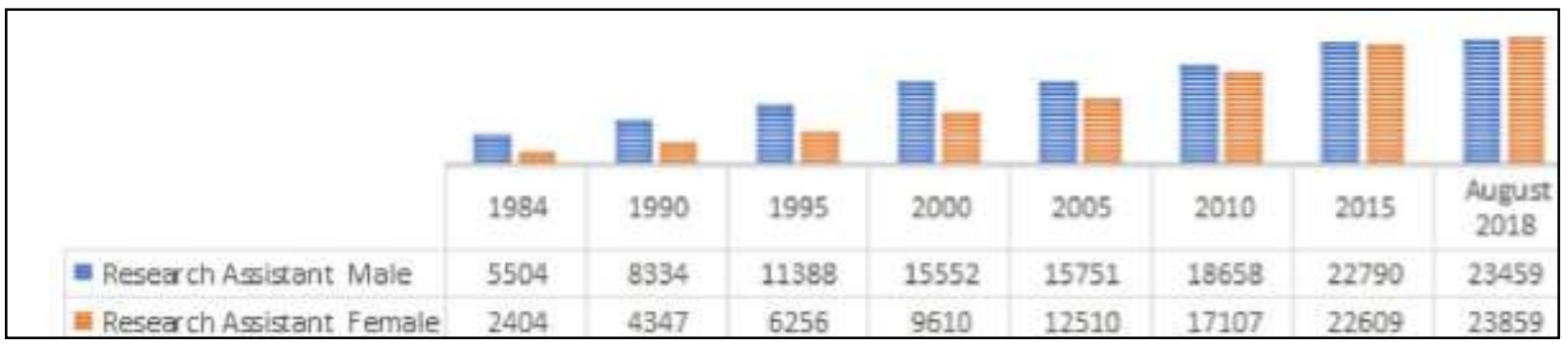

Graph 14. Distribution of the academicians in the research assistant position by gender

Source: CoHE, 2018

When the number of research assistants that is regarded as the starting point of academic career is examined (Graph 14), it is seen that the number of women have reached, with a very high increase rate, to the number of men in this position within the last five years and even passed the number of men at the present time.

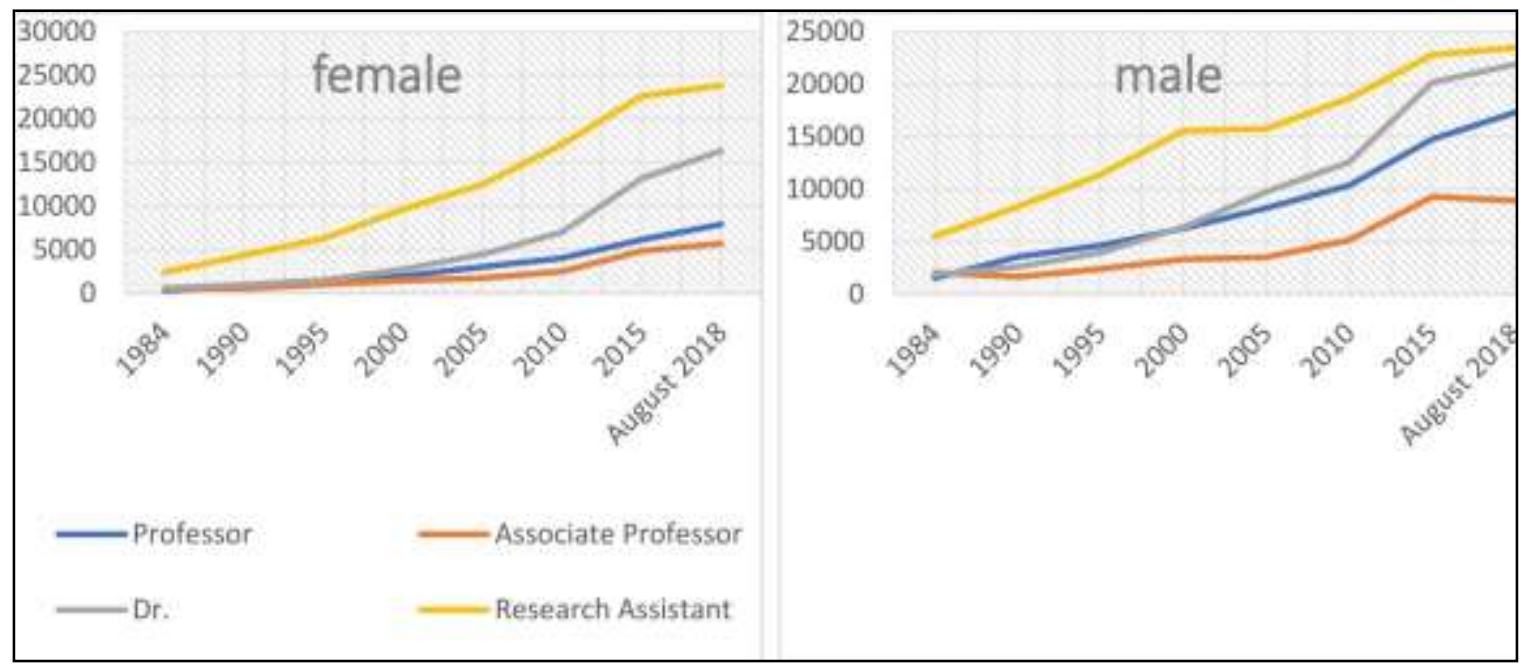

Graph 15. Comparison of academic promotion by gender

When the changes in the academic career steps given separately in the previous paragraphs are all examined together in terms of gender (Graph 15); it is observed that there is a similar increase in the number of male and female research assistants, which is regarded as the beginning of career. However, as we go up in career, it is observed that the increase seen in male academics did not occur at similar rates in female academics.

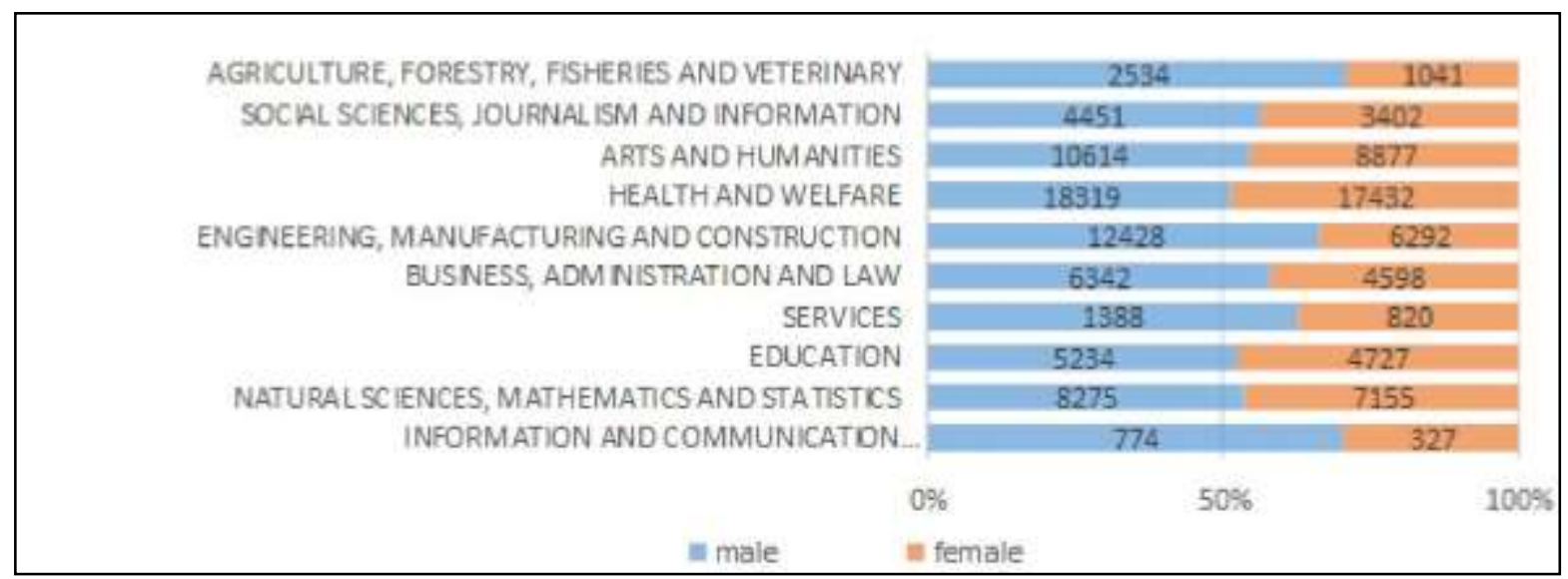

Graph 16. Number of teaching staff in undergraduate programs by classification of fields of education and training Source: CoHE, 2018

$$
\text { (2017-2018) }
$$


Another issue to be examined regarding gender equality in $\mathrm{HE}$ is that whether academic staff do or not put up a gendered table by their fields. The comparison of the academic staff employed in undergraduate programs by their fields and genders is given in Graph 16. It is observed that female academic staff are represented at least in agriculture, forestry, fisheries and veterinary, engineering and manufacturing, information and communication fields. The area where the highest gender equality is provided is health-welfare, natural sciences, mathematics and statistics and education science.

\subsection{Woman as an Administrator in $H E$}

Another indicator of gender equality is the representation rates of women in decision-making mechanisms. For this reason, the numerical situation of women in managerial positions of HE institutions is examined in this part of the research. In Graph 17, the rates of women in senior management of universities are given together with the academic staff ratio.

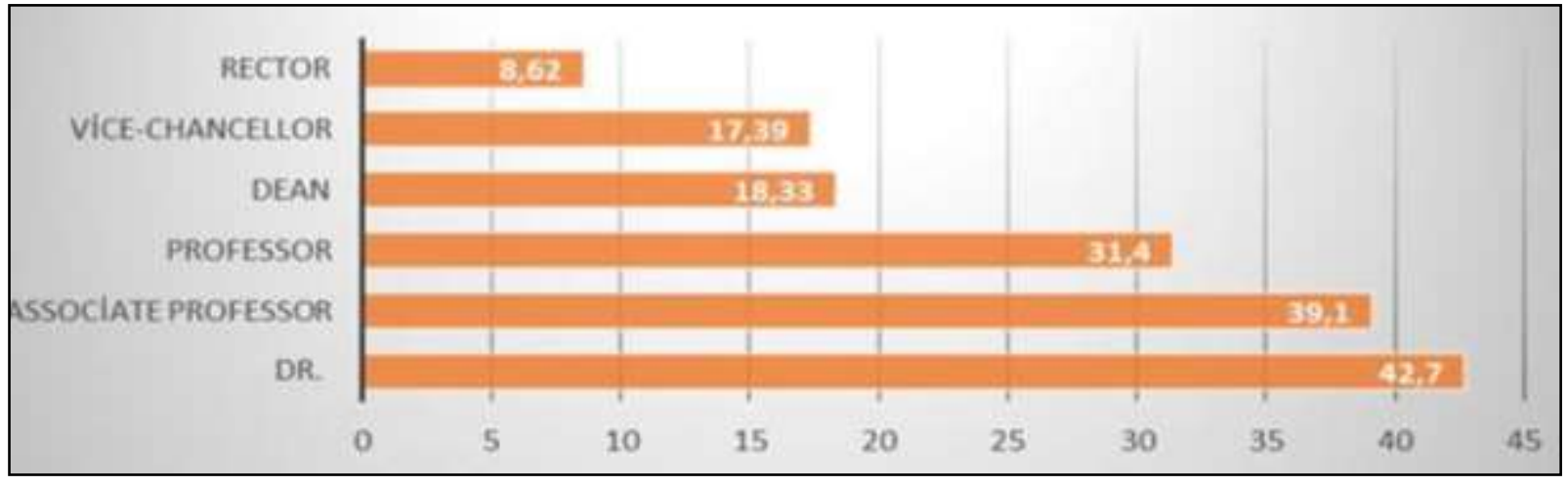

Graph 17. The rates of women in senior management of universities and in the academic staff

Source: CoHE, 2018

When the status of women in academic staff is examined, it is seen that the proportion of women is higher in Turkey $(44.5 \%)$ than in many countries (CoHE, 2018). This is a significant ratio, however, male domination is continuing in top positions such as rectorate $(8,62 \%)$. In HE level in Turkey, it is observed that women are underrepresented in decision-making mechanisms, when especially the proportion of women in the "Professor" staff that provide transition to senior management positions is taken into account.

\section{Discussion}

The fact that the relations and role distribution between women and men which are defined as gender concept is indicated by political, social and economic structures not by biological differences foresees that these roles and relations can be altered and restructured equally (Yumuş, 2011). What is important at this point is to determine the situations that create gender inequality and to eliminate the inequality by means of functional solutions. In this study which has examined the gender equality in Turkish HE, it has been concluded that the women are advantageous in schooling in HE and employment but they are exposed to inequality in advancing in career and participation in decision-making mechanisms.

As it is seen in developed countries, also in Turkey too, the participation and continuity of women in HE is higher than that of men. Sart and Sarıdoğan (2017) also found that the difference in enrolment rate based on gender in the EU countries was statistically significant and that the enrolment rate of women was higher than that of men. One of the main reasons of this situation is the advantage that women complete their HE to join in workforce. Määttä \& Dahlborg (2011) indicate that as the education level of women enhances, their chance to join the workforce enhances, too. EIGE relates high education level to a lower gender employment difference (Beijing+20: The Platform for Action (BPfA) and the EU policy paper). It demonstrates workforce participation levels of women and men according to education levels out of data of Turkey Statistical Institute (TurkStat) and that this advantage difference has a great validity in Turkey. According to the data of 2017, employment rate of illiterate men is 43.3\%, primary school graduates rate is $90.9 \%$, secondary school graduates rate is $73.5 \%$ and higher education graduates rate is $89.6 \%$. These rates are respectively $23.7 \%, 33.9 \%, 34.9 \%$ and $74 \%$ in employment of women. It is obvious that there is a huge risk/reward difference between men and women who continue their higher education due to professional concerns. While higher education is preferred to be a part of the workforce market on better terms for many men, it is 
compulsory for many women to be involved in any form of higher education to be involved in workforce market (Seskir 2017).

According to The Economic Policy Research Foundation of Turkey's report (Aş1k, 2013), the only way for Turkey to accomplish the gross domestic product per capita which is aimed for 2023 is the need of employing way more women. No matter how more the education levels and employment opportunities increases for women surprisingly and pleasingly, it is still seen that women are disadvantageous in income equality and Bobbitt-Zeher (2007) explains this situation with these education measurements: (1) the field choice at university, which are not generally the fields that offer high incomes and men generally focus on the fields that offer high income; (2) the skills that are measured via standard tests, especially math and science performances continue to be the wage indicator of the today's economy; (3) the reality that greater educational attainment result in higher wages for both women and men; (4) the prestige of the university which was attended to creates a significant change in the future's income levels and men are especially inclined to attend selective postsecondary institutions than women do.

In this study, it was concluded that Turkey made a great progress in employing women academicians and achieved a higher rate above world average. It can be said that woman academicians' rate is parallel with student gender balance considering that $46.5 \%$ of the undergraduate students, $39 \%$ of graduate students, $42.5 \%$ of postgraduate students are women as of 2017-18 education year. However, Kaya (2015) criticizes the increase in women rate in academies "illusion which is regarded as success" and indicates that this increase is the increase in employment of women in the fields which have monotonous order, the least career opportunities and work health and evaluates the feminization of "the lower class" of academies. Anyway, a remarkable increase in the rate of women who have academic titles has been monitored in approximately the last 3 decades.

However, it seems that women and men who are involved in academic processes relatively in near period at undergraduate and even at the doctoral level have gradually got away from each other in the later stages of their career processes. In other words, as the academic title levels increase, the women rate gets lower. In the light of this information, some studies point out the existence of class differences based on the gender in academic life (Öztan and Doğan, 2015).Even if Özkanlı and Korkmaz (2000) put forward that women academicians do not experience gender apartheid in academic career or management but the men academicians are "more advantageous" in higher academic career, the imbalanced gender situation can be described as both vertical and horizontal (Lindberg, Riis and Silander, 2011; Öztan and Doğan 2015): Vertical segregation: the women are in the lower levels of the academic hierarchy and the men are in the higher levels. This portrayal of women in HE forming a narrowing gendered pyramid shows that women are well-represented on undergraduate and post-graduate levels, but less well represented in the two permanent high positions: These are senior lectureships and professorships. Horizontal segregation: men and women are present to a different degree in different fields of HE. Focusing on vertical changes provides explanations placed only at an organizational level. However, this may impede the understanding of a multifaceted phenomenon, and can lead to contra-productive political measures.

Also the fact that the high rate of the woman academicians on the level of research assistant and assistant professor is not high on the level of professor and management positions (Graph 17) and also the fact that there is a decline in this rate as the title goes up is also a striking result of a research that was conducted on the vertical segregation which reflected the hardship women come across to get higher positions in academic career process. However, it is seen that even though the employment rate of women academicians in HE constitutions in Turkey is higher than that of western countries, this rate is very below the rate of UN $(20.1 \%)$ in the field of senior management on the same level (She Figures, 2015). The general explanations on the researches on such conditions in HE are as follows (Lindberg, Riis and Silander, 2011): (1) Women's own decisions: Academia is often metaphorically described as a pipeline (Shaw \& Stanton 2012), alluding that academic career is basically a rectilinear process from undergraduate education to tenured professorship. The academic career pipeline is conceived of as consisting of five discrete stages: undergraduate studies, graduate studies, post-doctoral fellowships, assistant professorship (tenure track) and tenured professorship. This pipeline generally "leaks"; that is, individuals may leave academia at various stages in the process. (2) Insufficient rate of their existence on high positions on organizational level: It can be explained via an invisible glass metaphor which prevents women to get higher positions. Glass ceiling is a simple segregation phenomenon based on gender, race or ethnical background and Burbridge (1994) explains this phenomenon towards woman as the barriers that women come across to upward mobility irrelevant to their characteristics and abilities. (3) The traditional female role in society: It is explained as women's preference to spare more time to their family and kids. Williams (2005) supports this explanation by "maternal wall" metaphor, which is a wall that restricts the women's progress once women become mothers and the individual who are not mother (including men) tend to move upwards when they reached an obvious success level. 
When the horizontal segregation which reflects the inequality in the distribution of disciplines in the academic life is taken into consideration, it is concluded that women academician in Turkey are presented less in the fields of agriculture, forestry, fisheries and veterinary, engineering and production, information and communication, and the most gender equality is ensured in the fields of health-welfare, natural sciences, mathematics and statistics and education science. It is seen that gender roles are prevalent in the job preferences that women choose and get (Özaydınlık, 2014). Nevertheless, Özkaplan (2013) notes that the separation of academic disciplines as man's and woman's work is an undesirable situation for the academy. Actually, the number of women graduates in the sub-fields of science and engineering generally enhance rapidly than the number of men and in Turkey. The proportion of women at $\mathrm{PhD}$ level within sub-fields (engineering and engineering trades, physical science, manufacturing and processing, mathematics and statistics) enhanced (She Figures 2015).The increase upon which Özkan and Doğan ( 2015) agree can be explained by the fact that hardworking women and men are being directed to science and math fields without the gender-related bias is a common practice in Turkey and the constitutions that supply qualified education can be accessed via a neutral central examination system in terms of gender equality. However, horizontal segregation patterns between science fields are becoming more visible on lower branches base.

England (2010) states that from 1971 to 2006 the number of women who doctorate in every field generally increased dramatically, but the percentage of doctoral students in terms of percentage changed just a little bit also claims that the extreme segregation in the fields of academic study enabled many women moving "up" to doctoral study and an academic career to do so in fields that seemed consistent with their (tacitly gendered) ideas of their interests and "ideal selves" Women academics studying on the humanities and social sciences thus are interested in the more woman subunits (disciplines) of a still largely man-dominated larger unit (the professoriate). To sum up, the fields that have highest percentage of women percentage today are those that already had a high percentage of women decades ago relative to other fields. While the percentage of woman professors in the field of physics, earth sciences and mathematics rates fall below 20\%, this rate in the areas of life sciences such as biology and chemistry, bio-technology environment has reached above $30 \%$. Particularly, biology department is noted with the $42 \%$ of women professor rate. While the woman professor rate in the field of social sciences and also in the fields of religion, philosophy, history and archaeology is below $20 \%$, in the field of foreign languages this rate is $45 \%$; in the field of educational sciences it is 34\% and in preschool education areas this rate is above $80 \%$ (Öztan and Doğan, 2015). Schiebinger (1989) suggests that women are more likely to be directed compatible areas (e.g., biology, botany) by traditional assumptions about women, and owing to that it is clear that there is a gender-related segregation within natural sciences itself. Keller (1983) asserts that women are also excluded from areas like physics by similar assumptions.

Another result concluded from the research conducted on the gender equality in HE in Turkey is that although averagely $43 \%$ of academicians and nearly $32 \%$ of professor staff consist of women, the $92 \%$ of the university rectors are male academicians. Suğur and Cangöz (2016) suggests that the main reason behind the gender-related problems of women academicians in Turkey and in the world is because women are not allowed in the decision-making mechanism of academic life. In reality, women are employed at a higher rate in the public service area. Contrary to this positive condition, the rate of women in the senior level decision-making position in the bureaucracy is low. $88.19 \%$ of the senior level executives in bureaucracy are men, only $11.81 \%$ are women (Women in Turkey, 2018, p. 56). When the same ratios are considered in terms of state universities, the rate of woman staff is $43 \%$ and the possibility for woman academicians to be manager is $15 \%$ (Tunç, 2016).

EIGE questions the reason why the improvement is so slow even though there are improvements in women rate in higher education and researches among European countries (Gender equality in academia and research, 2016, p.7). Despite some positive researchers in relation to the representation women in management positions in higher education (Blackmore and Sachs, 2001; Acker, 2005; Acker and Webber, 2006 cited in Thompson 2015) there is majority of researches that support women are not represented sufficiently in management positions (Kloot, 2004; O'Connor \& White 2011; Göransson, 2011; O'Connor 2011; Machado-Taylor and Özkanlı, 2013; Tahtalığlu, 2016; Shepherd, 2017). Machado-Taylor and Özkanlı (2013) state why women are represented insufficiently senior management in Turkish HE system can be explained by numerous complex factors. The people they interviewed for their researches (women and men) stated that they believed there is no obstacle for women to move up to senior management positions and also, they asserted that women creates their own obstacles. Shepherd (2017) who has the same opinion on this matter states that if individuals want to be successful in academic game, strategic agency is required and, on this matter, women are sometimes seem to be insufficient and they are not confident enough also they are not able to promote themselves. In addition to that, they are not chosen for senior management positions since they believe that they are unattractive and/or pretty demanding. Similarly, Özkanlı and Korkmaz (2000, cited in 
Machado-Taylor and Özkanl1, 2013) noted down that women in academic life have ever-increasing responsibilities stemming from their daily life and stated in their researches that some women academicians point out to the gender-related segregation for management positions while other ones accept the traditional societal roles of women and they are unwilling to undertake management responsibility since they adapted these roles. Y1ldiz (2018) also states that women academicians do not want especially senior management duties mainly because of the multi-roles of senior management duties and also personal preferences and anxiety deriving from learned helplessness about failure.

The main theme that needs to be discussed here is the factors behind the reasons why women are not managers. One of the factors might be the society's point of view toward leadership. On this matter, Sinclair (1998, cited in Kloot, 2004) suggests invisibility effect that "men and women are equal in leadership, but are perceived as different". Societal norms define the expected roles of behaviours of men and women, and managerial characteristics are often assigned to men. Men and women are judged differently for the same behaviour. Toren (1993), who focuses on culture of the institution as another factor, states that in the academic hierarchy the reason why women move upwards more slowly than their male colleagues should be seen as part of the cultural and institutionalized arrangements in the academy, not only as the individual characteristics of women (motivation, ability, fidelity). According to Toren, the slowness of women's progress in career improvement is approved to great extent and explained by "objective conditions" i.e. women's domestic duties and responsibilities. Furthermore, to Toren, the longer period between the promotions of men and women is not only accepted, but also more importantly conceptualized as a socially expected situation. Howe-Walsh and Turnbull (2016) concluded in a research conducted on science and technology in United Kingdom (UK) that women challenge in a sexist environment and this makes them to feel scared and consider to leave the organization.

The rate of women academicians in Turkish HE is higher compared to western countries and the research's results show that women academicians do not face with glass ceiling when climbing the steps of academic career. However, women are rarely presented in management/leadership positions of higher educational institutions. That's why, it can be said that women academicians in Turkey face glass ceiling not in academic career but in progressing in management positions. To come up with a solution this problem, in the Workshop on Developing and Strengthening Women's Leadership in HE (2012); by evaluating the factors that cause discrimination that Turkish women academicians are exposed to (academic working culture, legislation, socio-cultural factors and personal factors), solution suggestions to exceed the glass ceiling (to improving working conditions, making legal arrangements, strengthening women's relations networks, media support, , financial support, training and organization) have been proposed. In the Gender Equality in Academy Policy document (2015) prepared by the Sabanc1 University Gender and Women's Studies Forum, to prevent inequality and segregation, it has been proposed to establish Gender Sensitive Research Support to support academic career and to make a gender-sensitive institutional change in the academy. Similarly, correlative subjects have been discussed in the Training of Women's Leadership Development and Strengthening in HE (2013, 2014 and 2015) and in the Gender-Equality-Sensitive University Workshop organized by CoHE which took place for the first time in 2015. As The General Directorate on the Status of Women pointed out, since women's problems are linked to various areas, an integrated approach needs to be taken and not only national studies but also related institutions and constitutions need to reflect the concept of the opportunity equality to women and men to their policies and implementations. (Women's Empowerment Strategy Document and Action Plan, 2018). In this context, the criticized matters regarding lack and insufficiency of policies/legislations which promote women's leadership, lack of sanction power should be resolved immediately and urgently.

Cultural events have a direct effect on self-image and it ensures a ground for individual's improvement. As more women undertake leadership positions and become successful, the woman image will be altered to reach the personal success (Russell, 1979). More "Role Models" are needed for woman academicians to join decision-making process in $\mathrm{HE}$ and it is significant to make woman academicians who has exceeded "Glass Ceiling" more visible. In addition, it is also necessary to supply government support for the issues such as child and elderly care etc.to women to keep work-family life balance which is seen as anobstacle in woman leadership in HE.

Consequently, the main points of the problem have been detected to ensure the gender equality in Turkish HE and solution suggestion have been made in a general manner. In other words, it can be said that the first phase "denial" which does not perceive it as a problem that women in senior management typology as identified by Turkish HE cannot become managers has been exceeded as also defined by Sinclair (1998, p.19 cited in O'Connor 2011; in Kloot, 2004). Turkish HE should move forward to "the commitment to a new culture" phase, which recognizes that exclusion of women as an indicator of deeper problems that need to be found solutions by focusing on the existing culture. In this context, it is vital to form an atmosphere of men and women equality to make sure the social equality 
and universities to be woman-friendly. Women do not like to apply for jobs in vain because they know that they will not be hired or they do not want to be somewhere they feel like they will not be welcomed. For this reason, if women do not apply for a position of an institution, it should be assessed as the failure of that institution and they should make extra efforts to impress women (Valian, 2005).

In this study, only the rate of women has been examined in HE institutions both as students and academicians and they have been based on quantitative and open-to-public data. These have been discussed associating with the researches carried out in Turkey and other countries. This study has not made a deduction whether women have been exposed to inequality despite the increasing female rate in HE or not. For this reason, it is considered that it would contribute more to the field if this issue is examined in a wider perspective.

\section{References}

Adak N. (2018). Women in the Academy: Access to Higher Education and Career Advancement. Akdeniz Kadin Çalışmalarl ve Toplumsal Cinsiyet Dergisi, 1(1), 23-38.

Altınoluk, D. (2018). To Be a Woman, To Be an Academician? That's the Question. Fe Dergi, 10(1), 58-66.

Aşık, G. A. (2013). Türkiye'yi kadınlar büyütebilir mi? Türkiye Ekonomi Politikaları Araştırma Vakfı. Retreived from http://www.tepav.org.tr/upload/files/1361452044-2.Turkiye_yi_Kadinlar_Buyutebilir_mi.pdf

Aydın H. (2015). Meşrutiyet'ten Cumhuriyet'e Türkiye'de Kadın. Current Research in Social Science, 1(3), 84-96.

Beijing+20: The Platform for Action (BPfA) and the European Union Area B: Education and Training of Women European Institute for Gender Equality (EIGE).

Bingöl, O.(2014). Toplumsal Cinsiyet Olgusu ve Türkiye'de Kadınlık, KMÜ Sosyal ve Ekonomik Arastırmalar Dergisi, 16(I), 108-114. https://doi.org/10.18493/kmusekad.36760

Burbridge, L. C. (1994). The glass ceiling in different sectors of the economy: differences between government, non-profit, and for-profit organizations. Glass Ceiling Commission, US Department of Labor, Washington. Retrieved from http://digitalcommons.ilr.cornell.edu/key_workplace/119.

Bobbitt-Zeher D. (2007). The gender income gap and the role of education. Sociology of Education, 80(1), 1-22. https://doi.org/10.1177/003804070708000101

Council of Higher Education (CoHE), (2018). 2017-2018 Academic Year HE Statistics. Retrieved from https://istatistik.yok.gov.tr/

Çalışkan Maya, İ. (2012). Women's Participation in the Administration of Higher Education: Policies-Strategies Pursued By Some EU Countries, and Recommendations to Turkey. Ahi Evran Üniversitesi Kırşehir Eğitim Fakültesi Dergisi, 13(3), 207-226.

England P. (2010). The gender revolution: Uneven and stalled. Gender \& Society, 24, 149-66. https://doi.org/10.1177/0891243210361475

European Commission. (2016). She Figures 2015, Gender in Research and Innovation, Brussel.

Gender Equality in Academy Policy Document. (2015) Sabanc1 University Gender and Women's Studies Forum Retrieved from https://aciktoplumvakfi.org.tr/pdf/akademi14122015.pdf.

Gender equality in academia and research. (2016). European Institute for Gender Equality (EIGE)

Global Partnership for Education (GPE) Policy Brief. (2016). Advancing Gender Equality in Education Across GPE Countries.

Retrieved

from https://www.globalpartnership.org/content/policy-brief-advancing-gender-equality-education-across-gpe-countri es

Goransson, A. (2011). Higher education and gender equity. In B. Bagilhole and K. White (eds.), Gender, Power and Management: A Cross-Cultural Analysis of Higher Education, Basingstoke: Palgrave Macmillan, 50-77.

Günay, D., Günay A. (2016). Higher Education Enrolment Rates and Improvements in Turkey and in the World, Journal of Higher Education and Science, 6(1), 13-30. https://doi.org/10.5961/jhes.2016.139

Howe-Walsh L. \& Turnbull S. (2016). Barriers to women leaders in academia: tales from science and technology, Studies in Higher Education, 41(3), 415-428. https://doi.org/10.1080/03075079.2014.929102

Karakuş H. (2016). Leaky pipeline: an analysis on female academics in Turkey. International Journal of Social Science, 53, 533-556. https://doi.org/10.9761/JASSS3635 
Kaya, C. İ. (2015). Is the increase in the number of women in academia a success or a hidden face of inequality? In Ağridağ, G. (Ed.) Research on Woman in Turkey and the World, Çukurova University Publishing House. Adana, Turkey.

Keller, E. F. (1983). Reflections on Gender and Science, New Haven: Yale University Press.

Köker, E. (1988). Women in Turkey, education and politics: an examination of the situation of women in higher education institutions, Unpublished Doctoral Dissertation, Ankara University, Ankara.

Kloot, L. (2004). Women and leadership in universities: a case study of women academic managers, International Journal of Public Sector Management, 17(6), 470-485, https:// doi.org/10.1108/09513550410554760

Kjeldal, S.-E., Rindfleish, J., \& Sheridan, A. (2005). Deal-making and rule-breaking: behind the facade of equity in academia. Gender and Education, 17(4), 431-447. https://doi.org/10.1080/09540250500145130

Lewis, S., Humbert, A. L. (2010) Discourse or reality?: Work-life balance, flexible working policies and the gendered organization. Equality, Diversity and Inclusion: An International Journal, 29(3), 239-254, https://doi.org/10.1108/02610151011028840

Lindberg, L., Riis, U. \& Silander, C. (2011). Gender Equality in Swedish Higher Education: Patterns and Shifts. Scandinavian Journal of Educational Research, 55(2), 165-179. https://doi.org/10.1080/00313831.2011.554697

Machado-Taylor, M. de L., \& Özkanl1, Ö. (2013). Gender and academic careers in Portuguese and Turkish higher education institutions. Education and Science, 38(169), 346-356.

Määttä, S., Dahlborg, L. E. (2011). The influence of gender in academia: a case study of a university college in Sweden. Equality, Diversity and Inclusion: An International Journal, 30(5), 379-393. https://doi.org/10.1108/02610151111150636

Maya, İ. (2013). A comparison of gender inequality in Turkish education system with that of EU countries. Education and Science, 38(168), 69-84.

Ministry of National Education statistics. (2017). The Republic of Turkey Ministry of Education, Ankara, Turkey.

O'Connor, P. (2011). Where do women fit in University Senior Management? An Analytical Typology of Cross National Organisational cultures' In: Bagilhole B., White K. (eds) Gender, Power and Management. Palgrave Macmillan, London, 168-191. https://doi.org/10.1057/9780230305953_8

O'Connor P., White K. (2011). Similarities and differences in collegiality/ managerialism in Irish and Australian universities, Gender and Education, 23(7), 903-919. https://doi.org/10.1080/09540253.2010.549109

OECD. (2018). Population with tertiary education (indicator). doi: 10.1787/0b8f90e9-en (Accessed on 21 August 2018). https://doi.org/10.1787/0b8f90e9-en

Özaydınlık K. (2014). Women in Turkey on the basis of gender and education, Sosyal Politika Çalışmaları Dergisi, 14(33), 93-112. https://doi.org/10.21560/spcd.03093

Özkaplan, N. (2013). Kadın akademisyenler: cam tavanlar hâlâ çok kalın [Women academıcıans: glass ceilings are still too thick]. Kadın Araştırmaları Dergisi, 1(12), 1-23.

Özkanlı, Ö., Korkmaz, A. (2000). Turkish Women in Academic Life: Attitude Measurement towards Gender Discrimination in Academic Promotion and Administration. In Emerging Economies: Academy of Business Administrative Sciences International Proceedings, Prague: St Bonaventure University, Prag.

Özkul, A. S., Baysal, H. (2017). Entrepreneurship Codes in Higher Education for Women in the Last Period of Ottoman Empire: Darulmuallimat, Inas Darulfunun and Ticaret Mektebi Alisi. SDU Faculty of Arts and Sciences Journal of Social Sciences, 41, 1-20.

Öztan, E., Doğan, S. N. (2015). The Domestic' of the Academia: Science, Gender and The Case of a Technical University, Çalışma ve Toplum, 3, 191-221.

Russell, D. H. (1979). How a scientist who happens to be female can succeed in academia. Annals of the New York Academy of Sciences, 323(1), 283-295. https://doi.org/10.1111/j.1749-6632.1979.tb16862.x

Sart G., Sarıdoğan E. (2017). A statistical analysis for the gender gap in college enrollment in EU countries, Istanbul University Journal of Women's Studies, 1, 9-16.

Savigny, H. (2014). Women, know your limits: cultural sexism in academia. Gender and Education, 26(7), 794-809. https://doi.org/10.1080/09540253.2014.970977 
Schiebinger, L. (1989). The mind has no sex, Cambridge, Mass: Harvard University Press.

Shaw, A. K., Stanton, D. E. (2012). Leaks in the pipeline: separating demographic inertia from ongoing gender differences in academia. Proceedings: Biological Sciences, 279(1743), 3736-374. https://doi.org/10.1098/rspb.20 12.0822

Seskir, Z. C. (20017). Possible Causes and Effects of the Changes in Quantitative Gender Gap in Turkish Higher Education. Journal of Higher Education and Science. https://doi.org/10.5961/jhes.2017.211

Suğur, S., Cangöz, İ. (2016). Üniversite yönetiminde kadınların eksik temsili üzerinde toplumsal cinsiyet ilişkilerinin rolü. Amme İdaresi Dergisi, 3(49), 89-115.

Shepherdb S. (2017). Why are there so few female leaders in higher education: A case of structure or agency? Management in Education, 31(2), 82-87. https://doi.org/10.1177/0892020617696631

Tahtalioğlu, H. (2016). The effects of glass ceiling syndrome on women in higher education institutions in Turkey. Niğde Üniversitesi İktisadi ve İdari Bilimler Fakültesi Dergisi, 9(2), 89-105.

The Global Gender Gap Report. (2017). The World Economic Forum, Geneva, Switzerland.

Thompson, B. M. (2015). Succumbing, surviving, succeeding? Women managers in academia. Gender in Management: An International Journal, 30(5), 397-413. https://doi.org/10.1108/GM-08-2013-0095

Toren, N. (1993). The temporal dimension of gender inequality in academia. Higher Education, 25, 439-455. https://doi.org/10.1007/BF01383846

Tunç A. (2016). Proportion of executive women in Turkish public personnel administration a review of state universities. Yasama Dergisi, 32, 64-80.

UNESCO Priority Gender Equality Action Plan 2014-2021. Retreived form http://unesdoc.unesco.org/images/0022/002272/227222e.pdf.

Uysal, D., Ersun Aydemir, E. (2016). Concept of higher education and analysis of impact of higher education on employment and economy in Turkey. Selçuk Üniversitesi Sosyal Bilimler Enstirüsü Dergisi, 35, 275-284.

Valian V. (2005). Beyond Gender Schemas: Improving the Advancement of Women in Academia, Hypatia, 20(3), 198-212. https://doi.org/10.1111/j.1527-2001.2005.tb00495.x

Williams, J. C. (2005). The glass ceiling and the maternal wall in academia. New Directions for Higher Education, 130, 91-105. https://doi.org/10.1002/he.181

West, C., Zimmerman, D. H. (1987). Doing Gender. Gender and Society, 1(2), 125-151. https://doi.org/10.1177/0891243287001002002

World Bank Group Gender Strategy Paper 2016-2023.

Women in Statistics. (2017). TurkStat (Turkish Statistical Institute), Retrieved from http://www.turkstat.gov.tr/.

Woman in Turkey. (2108). The Republic of Turkey Ministry of Family and Social Policies, The General Directorate on the Status of Women, Ankara.

Yenilmez, M. İ. (2016). Women in academia in Turkey: Challenges and opportunities. Journal of Administrative Sciences, 14(28), 289-311.

Yıldız S. (2018). Being a Female Academician in Turkey. Journal of Higher Education and Science, 8(1), 29-40. https://doi.org/10.5961/jhes.2018.245

Yıldırım, A., Şimşek, H. (2013). Sosyal bilimlerde nitel araştırma yöntemleri [Qualitative research methods in the social sciences]. Ankara: Seçkin Yayıncılık

Yılmaz, G. A. (2017). Women's place at Marmara Unıversity. Marmara Üniversitesi Kadın ve Toplumsal Cinsiyet Araştırmaları Dergisi, 1, 1-15. https://doi.org/10.26695/mukatcad.2017.0

Yumuş, A. (2011). Kalkınma planları çerçevesinde toplumsal cinsiyet eşitliği anlayışının ekonomik, toplumsal ve siyasal boyutlart, The Republic of Turkey Ministry of Family and Social Policies, The General Directorate on the Status of Women, Ankara, Turkey.

Workshop on Women's Leadership in Higher Education. (2012). Düzce University, Turkey. 